\title{
CURRENT CHALLENGES IN THE REGULATION AND ACTIVITIES OF THE FINANCIAL SECTOR IN THE EUROPEAN UNION (2019-2024)
}

\author{
Péter Vass - Levente Kovács
}

\begin{abstract}
At the start of the new European parliamentary cycle, it is useful to draw up a balance and make a summary overview of the main challenges and future tasks which the European financial sector can be expected to face in the next five-year cycle, as well as the inherited problems in which progress is imperative. A good proportion of the problems still stem from regulatory and market responses to the financial and economic crisis that assumed global dimensions in 2008, what many refer to as the "great financial crisis"; however, issues arising from the qualitative leap in technological development and the sustainability of economic mechanisms attract ever-growing attention these days. All these open up new directions in which individual institutions on the financial markets are able to adapt, sometimes creating opportunities, but sometimes difficulties and institutional failures.

This study aims to present a summary of the most important directions of change in the operating environment. It does not extend to a deeper examination of the individual topics concerned, but rather illuminates the processes from the perspective of banks as they strive to maintain sustainable growth, articulating their expectations.

In shaping the structure of this paper, we have used the recommendations of the European Banking Federation, sent to European institutions and legislators following the recent European elections (EBF, 2019), in which the body presents the necessary regulatory measures within each of the principle areas of concern.
\end{abstract}

JEL codes: G21, O16, G18, K20

Keywords: bank, bank regulation, financial supervision, banking union, sustainability, economic growth, financial literacy

1 Péter Vass, Deputy Secretary-General, Hungarian Banking Association. Email: vass.peter@ bankszovetseg.hu.

Kovács Levente, Secretary-General, Hungarian Banking Association. Email: kovacs.levente@ bankszovetseg.hu. 


\section{STABLE AND EFFICIENT REGULATION, PRESERVING THE ACHIEVEMENTS OF FINANCIAL STABILITY}

A vast amount of analysis has already dealt with the root causes of the great financial crisis, and with evaluating the regulatory responses to it. In the EU, besides global expectations, attention also needed to be paid to specific national growth trajectories, efforts aimed at further strengthening integration, and special focuses deriving from the mutual impact of all these factors. In contrast with the complexity of the given issues, the available time to carry this out was limited, so that - despite constant demand from the financial sector - a thorough exploration of the complex interplay of methods of dealing with individual problems and areas of concern, and the preparation of relevant impact studies, did not take place.

Today the financial sector has become global, and the mainstream of the European regulatory processes that are mapping it out is in the implementation phase. At the institutional level, preparations are continuous and the direction of real, complex compliance of the financial sector is slowly moving back towards regulation, so that the reciprocal effects can be examined within a real operating environment and the degree of efficacy of earlier chosen regulatory solutions becomes measurable.

The process of compliance arising from the Basel regulatory framework itself presents institutions with great difficulties. The $\mathrm{BCBS}^{2}$ regularly measures the process of implementation in regulatory areas falling within its remit (capital requirement, leverage, liquidity, maturity mismatch). During preparation of one of its most recent surveys (BCBS, 2019a), besides examining compliance with individual regulatory instruments within different jurisdictions, the committee also looked at how the interaction of various regulatory areas collectively impacts the strategy and objectives of institutions. Based on the survey per se, it pinpointed no major negative reciprocal impact among the aforementioned areas, with the surveyed banks generally highlighting the complexity of the framework, as well as the volatility of the regulatory environment connected to the framework's implementation, as among the most significant challenges, beyond fulfilment of regulatory capital requirements. At the same time, it should be stressed that, by virtue of extending only to matters within the remit of the BCBS, the survey did not take stock of the difficulties arising from the collective impact of regulations that fall outside its scope.

2 Basel Committee on Banking Supervision 
In 2015, the European Commission launched its REFIT ${ }^{3}$ programme, which, through the work of the REFIT Platform, made recommendations - among other areas of jurisdiction - in certain spheres of financial regulation. However, it proved primarily useful in targeting the elimination of obvious regulatory inconsistencies. Among these, we could mention as examples recommendations designed to eliminate the differentiated supervision of financial conglomerates; to narrow reference rate expectations to the use of indicators on a pan-European level; to cancel overlapping provisions of $\mathrm{MiFID}^{4}$ II and Solvency ${ }^{5}$ II; to harmonise and simplify reporting obligations for securities financing transactions and other reporting regimes - e.g. related to EMIR $^{6}$ or UCITS7 guidelines; and to remove the barriers to digitalisation erected by financial regulations: in which instances, with the exception of the first two proposals, review processes are under way. Because the actual implementation processes of individual, mutually impacting regulatory regimes are yet to be completed, the proof of the principles may only be thoroughly tested following a review of banks' practical solutions to these questions. Digitalisation will present its distinct problems, as will methods of regulation that concentrate primarily on institutional ratings, which do not examine organisations and platforms outside the banking sector to the same depth as those within it, despite their undertaking very similar levels of risk.

At present banks are obliged to supply a vast amount of information to various authorities, from financial micro- and macroprudential supervisory bodies, to budgetary, tax and investigative authorities, to other organisations fulfilling various official remits. In practice, almost all data channels and data reporting structures are created independently from one another, with a negligible number of initiatives whereby authorities determine requirements of this nature in collaboration with each other. The accusation is often made against the banking sector that its systems are not quick enough to exploit the opportunities arising from technological advancement, and yet if we examine things only in terms of the number and variety of data connections, then the sheer scale of difficulties related to the constant demand for developments becomes understandable. Substantial internal banking resources could be freed up if authorities would cooperate with each other and ensure that, from the point of view of content, banks would only

3 Regulatory Fitness and Performance

4 Markets in Financial Instruments Directive

5 Directive on the taking-up and pursuit of the business of Insurance and Reinsurance

6 European Market Infrastructure Regulation

7 Undertakings for the Collective Investment in Transferable Securities 
need to furnish state and official bodies with each piece of data once, and based on identical technical requirements.

The administrative burdens of regulation following the financial crisis impacted small and medium-sized banks particularly hard. Interpretation of the principle of proportionality evolved in a very peculiar way among the ESAs ${ }^{8}$ and supervisory authorities of individual member states. The requirements appearing in norms at the EU level, irrespective of their relevance in the case of an institution operating with a simple business model, and thus with limited risk, were for the most part interpreted to extend to the entire sector. Explicit reference was seldom made to less stringent requirements applying to smaller institutions on the basis of certain criteria, although their application was not typical of the wave of (over) regulation. Consequently, the principle of proportionality is currently taken into consideration only to a limited extent in practice, particularly within administrative and reporting requirements. This, incidentally, is a phenomenon that is discernible not merely at the EU level. According to a survey by the BCBS (BCBS, 2019b), although the Basel framework - from its initial introduction to this day - has consistently prescribed application as an obligation only on banks active in the international sphere, it nevertheless enables individual jurisdictions to apply it more strictly and extensively. Almost everywhere, the consequence is that the rules are also applied to small, non-complex institutions, even though - based on certain metrics - smaller institutions could apply more lenient rules in several areas.

It is difficult to precisely measure the role and impact of small and medium-sized banks within the financial ecosystem. The general view, however, is that they may ensure greater diversification and territorial service coverage, while operating with limited risk due to their use of a simple business model, thereby having a potentially favourable influence on financial stability at both national and community level. For this reason, the "banking package" announced at the beginning of June 2019 (Regulation (EU) 2019/876, 877; Directive (EU) 2019/878, 879) attempts to introduce metrics that also take into account the specific characteristics of individual member states, softening the obligations on smaller institutions in several areas. Even so, another important step would be to apply the requirements of proportionality consistently by reviewing regulatory frameworks in other areas. While the beneficial effects of diversity on stability have been recognised, a number of regulatory or supervisory institutions in both Europe and in individual member states have been stressing that one structural weakness of the EU bank-

8 The European Supervisory Authorities: the European Banking Authority, the European Securities and Markets Authority, and the European Insurance and Occupational Pensions Authority. 
ing sector is its "overbankedness," which hinders its global competitiveness and sustainable profitability. By applying the principle of proportionality in keeping with actual risks, the evolution of the correct proportions of institutional diversity can be entrusted to the financial markets.

It is precisely since the advent of overregulation, excessive data and information provision, and various capital, liquidity and other requirements, that the fear of being "too small to survive" has spread. This holds that the aforementioned factors accelerate mergers to excessive size, or lead to bankruptcy of smaller players, as a consequence of which a concentration may come about that kills innovation and market competition in the sector.

\section{GLOBAL FINANCIAL REGULATORY PROCESSES - OPEN QUESTIONS IN THE EU}

Financial markets are global and market players compete on a global stage. For this reason, financial regulatory regimes need to be coordinated as much as possible on a global level as well. It is important, however, to take into consideration the disparate models that have evolved on individual key markets. Globally overextended local or national regulations take away the competitiveness of the local banking sector, which can translate into higher costs for local businesses or insufficient support for their entry onto global markets.

With the authorisation of the G2o granted at the Hangzhou summit in September 2016, the BCBS made a recommendation in 2017 for the finalisation of the Basel III regulatory framework (BCBS, 2017), whereby it primarily fine-tuned the rules on calculation of capital, citing as justification the need to restore credibility in the calculation of risk-weighted assets and improve the comparability of banks' capital ratios among various jurisdictions. The aforementioned G2o authorisation set as a criterion of the reforms that the sum total of banks' capital requirements (at the global level) should not increase (G2O, 2016). This, however, is taking shape in very disparate ways due to the markedly different business models of the banks operating within the various jurisdictions. Banks in the EU are put at a significant competitive disadvantage compared to certain developed markets, since - due to their comparatively fragmented, and thus relatively underdeveloped securitisation and claims management markets, as well as for reasons of the legal environment - they maintain significant credit risks on their own balances and continue to manage their non-performing exposures themselves for relatively long periods. In addition, the application of risk-sensitive internal credit risk models is more widespread, and consequently the BCBS proposal signifies a very 
substantial surplus capital requirement for these banks if introduced without taking into account distinctive European characteristics.

As an impact of the BCBS recommendations at the implementation stage, the EBA (EBA, 2019) has predicted a surplus capital requirement of close to $20 \%$; moreover, in the case of eurozone-headquartered global systemically important institutions (G-SIIs), this may exceed $28 \%$. The stability of European banks has been considerably enhanced on the back of already implemented Basel III rules; however, as a consequence of subsequently discussed profitability problems, in which the increased cost of capital owing to the aforementioned rules also plays a role, this will present the banking sector with significant challenges, primarily in the case of institutions aiming to secure capital on open markets. This is particularly problematic in light of the fact that the BCBS recommendations with respect to trading book risks were expanded to include new elements in January 2019, the probable future effects of which are yet to be included in the above EBA estimates. The current implementation of regulations strengthening the capacity of institutions to absorb losses represents similar difficulties. The EU has introduced mandatory instruments of recovery and resolution not just for global systemically important institutions, but for almost all credit institutions. The application of this in practice, which in many cases occurs through the issuing of securities, places a considerable burden not only on small and medium-sized banks, but also on larger institutions carrying out traditional commercial banking activities. Based on an EBA risk assessment (EBA, 2018), these institutions still had securities issues ahead of them at the start of the year, with pricing and its effect on profit presenting the greatest challenge.

Besides global regulations on capital requirements and resolution, another process with a potentially major impact in the near future could be the transformation of the presently prevalent European reference interest rates. This partly means the introduction of completely new, unsecured benchmark risk-free rates (RFRs) - almost exclusively of one-day maturity - or a significant methodological reform of existing unsecured interbank offered rates (IBORs) - mainly of longer maturities of up to one year, where a sufficient number of market transactions is typically guaranteed. At first glance, the change may seem unremarkable. However, the extraordinarily large number of contracts containing reference rates, coupled with their widespread application in risk management transactions, constitutes a significant administrative challenge at systemic level. It is thus no accident that the Financial Stability Board (FSB), in a letter (FSB, 2019a) to the International Swaps and Derivatives Association (ISDA), urges that new contracts contain clauses in the event of the termination of LIBOR rates. In addition, with regard to existing contracts, since authorities abstain from facilitating this transition with administrative prescriptions, the legal risks would need to be borne by 
the banking sector in the case of contracts in progress at the time of a potential change.

Additionally complicating the situation is the EU Benchmarks Regulation (Regulation (EU) 2016/1011), which raises important expectations with respect to reference interest rates, as well as to administrators and contributors to IBORs (panel banks, calculation agents, etc.), which - in the case of certain reference rates cannot be fulfilled, or which participants have no interest in fulfilling. Consequently, these may no longer be quoted following the implementation deadline, or their maintenance cannot be guaranteed until the entire affected stock of existing contracts runs its course, thus leading to the potential appearance of the aforementioned legal risk. According to the EBA's risk assessment (EBA, 2018), eurozone banks are aware of these impacts, with $85 \%$ of surveyed institutions working on preparations to replace the one-day IBORs, and 90\% deeming the problem related to existing contracts as a substantial challenge.

The new EURIBOR determination methodology began on 2 October 2019 within the administration of the European Money Markets Institute (EMMI), whereby reference interest rates are determined based on prices in real market transactions, so that their publication occurs on day $\mathrm{T}+1$ ). For users, this delivers a more transparent and market-oriented price than with any previous methodology.

\subsection{Deepening financial union}

\subsubsection{Banking Union}

Finalisation of the structure of the legal and institutional framework of banking union is an indispensable condition for the development of unified financial markets. Two of the three pillars of banking union - the Single Supervisory Mechanism and Single Resolution Mechanism within the eurozone, also including the voluntary accession of member states outside it - were already established in 2014. However, as the third pillar, the European Deposit Insurance Scheme (EDIS) - due, not incidentally, to the prolonged poor health of the financial systems of South European member states, and the consequent reluctance of member states with robust financial systems such as Germany and France - still finds itself caught within the crossfire of political skirmishing. Among the arguments listed in favour of EDIS, beyond the creation of a unified banking market, it is said that it would be capable of handling bankruptcies of national institutions at a level at which national deposit guarantee schemes are incapable on their own. In addition, at a certain level, it would render the entire deposit insurance system more resistant to cyclical effects, so that confidence in individual banks would not depend on their location within the eurozone, while it might also lessen the likelihood of an excessively self-perpetuating relationship evolving between banks 
and public debt, all of which could be ensured with a lesser level of contributions on the part of individual banks. On the other hand, the scheme's critics argue that while transfers of contributions and risks would occur among institutions or member states small and large, and stable and not so stable, it is precisely this level of protection that would demotivate member states with currently ailing banking systems from making painful structural adjustments, so that the scheme would also prove inadequate for managing bankruptcies of global systemically important institutions, with even the anticipated cost efficiency not sure to materialise. Clearly characterising the political nature of the debate, while the ECB (ECB, 2018) notes that the aforesaid problems of a political nature could be mitigated with well-chosen, differentiated fee payments in proportion to risks measured in the eurozone, conciliation talks among respective legislators are nevertheless still only proceeding slowly.

The free flow of capital and liquidity is ensured from the regulatory side among individual institutions within the territory of the banking union. However, the technical execution of this entails significant transaction costs. Banking union consummated as a consequence of implementation of EDIS could bring a major reduction in this regard, in so far as it would result in the possible removal of barriers to taking capital and liquidity into account across borders within banking groups operating in various member states. Capital and liquidity transactions between institutions within a group would thus become redundant, since the entire group would be able to operate as a kind of liquidity and capital pool. In the absence of a unified European Union deposit insurance fund, it is unlikely that any member state would be inclined at the political level to permit the liquidity or capital deficits of institutions operating within its jurisdiction to be covered by the liquidity or capital surpluses of foreign members of the given banking group. From this perspective, and in light of the above-listed general advantages, it would therefore be in the fundamental interests of the big European banking houses to conclude the political debate and introduce unified deposit insurance, provided it were to be accompanied by the aforementioned regulatory changes.

\subsubsection{Capital Markets Union}

A healthy, globally competitive European corporate environment and the mobility of investments cannot prevail without the presence of a unified capital market. In Europe it is still typical for capital markets to be splintered along member states' borders, obstructing the basic expansion of activities beyond these borders, and thus the development of a range of products at the European level. In the absence of this, the EU will be unable to reach the degree of financial integration of the North American continent, as the private capital investment solutions that 
best promote an innovative environment remain less widespread, thus leaving it behind in terms of global competitiveness.

The separation of the money and capital market textbooks is not so readily apparent in the practical operation of the banking sector. In the majority of EU member states, institutions operating on the traditional banking market are the most important agents of investment services, particularly in the retail and SME sectors. Consequently, an efficient pan-European capital market, besides providing financial stability, would have a favourable impact on the operational efficiency of the banking sector.

The elaboration of a regulatory framework for the establishment of the Capital Markets Union was one of the key strategic goals of the outgoing European Commission. Among other special policy measures, this included the initiation of 13 regulatory acts, dossiers which the Commission had planned to close by the end of its cycle (EC, 2015). However, execution of the plan of action proved slower than previously imagined, and by the end of autumn 2018 only three of the planned legislative processes had been completed, while only another two had reached the advanced stage of trialogue talks from which they could be comparatively quickly closed. The Commission issued a communication at the end of November in a bid to accelerate political negotiations and to be able to fulfil its original commitments (EC, 2018c), with partial success, since by the end of June two regulations had been promulgated, while another two had reached the stage of agreement at trialogue level, being signed by leaders of the European Parliament and the Council of the European Union and ready for promulgation.

The closure of the regulatory process, implementation, and particularly the exploration of further issues to be tackled with regulation at the EU level, will be critical in deepening integration on capital markets. The cooperation of European and individual member states' regulators with market players will be indispensable in achieving this. The good practices of more developed capital markets must be revealed and, as much as possible, adapted to all member states. In addition, regulatory and other market development tools must be applied to promote the evolution of local financial ecosystems everywhere, in which the spread of private equity investments must be incentivised, complementing the activity of open markets. A genuine, but safe securitisation market must be helped to develop, while reviewing why the framework renewed in 2017 did not permit the anticipated scale of growth to materialise. 


\subsection{Financing sustainable growth}

The Paris Climate Agreement and the UN Sustainable Development Goals outline global guidelines aimed at decarbonising the world economy and eliminating dependence on, and consumption of, fossil energy sources. The financial aspects of this were elaborated by the UNEP FI ${ }^{9}$ under the title Principles for Responsible Banking (UNEP FI, 2018), and brought up to date to reflect changes.

The UNEP FI was created in 1991 within the framework of the UN Environment Programme, its founding members being major commercial banks, with membership extended not long after to investment houses and insurance companies. Currently it has 141 member banks. It carries out its activities primarily through an annual general meeting and its secretariat, the main goal of which is to provide technical assistance and share good practices, and through this to establish standards at the initiative of the private sector.

The European Commission looks on developments related to sustainable economic growth as a tool to help arrest the EU's loss of economic ground and restore its earlier positions, and for this reason desires to obtain a leading role in relevant global initiatives. In the financial sphere, the framework for this is provided by its sustainability action plan (EC, 2018a), in which the main policy line is defined as follows: "1) improving the contribution of finance to sustainable and inclusive growth by funding society's long-term needs; 2) strengthening financial stability by incorporating environmental, social and governance (ESG) factors into investment decision-making." To attain these goals, the action plan earmarks the formulation of two new regulations at the primary level (of directives or regulations), as well as the amendment of several existing legal measures. Perhaps the most important of these is the regulation, constituting the core of implementation, which aims to establish an EU system of classification (a so-called taxonomy) of activities related to sustainability (EC, 2019), defining the criteria that serve as the basis for deciding whether an economic activity is sustainable from an environmental perspective. The appropriate framing of this taxonomy is critical, since it serves as the foundation on which to build practical implementation by financial service providers of the further elements of the action plan. It is no accident that while the process of approval of legislation within other elements of the action plan has already been completed, or is at an advanced stage, work on this issue is still ongoing within legislative bodies.

For banks, the focus on sustainability criteria signifies a twofold task. On the one hand, based on the given bank's current business model, and its clientele's

9 United Nations Environment Programme Finance Initiative 
branch of the economy and activity within it, it must assess the expected impact of changes in the environment and the resultant financial and profitability risks, or to be more specific the credit risk. On the other hand, it must characterise its own activity based on sustainability criteria. The new taxonomy will be central to both of these tasks, consequently it is an important requirement for it to be harmonised as far as possible with the EU's existing systems of environmental classification in relation to economic activity, providing unequivocal definitions for the sector which can be implemented as easily as possible and in an automated way. In addition, it is important that this information should be generated in a credible and reliable way in terms of taxonomy, and that validating it should not be the task of providers of financing or capital market services, but should fall instead to national or EU authorities.

For the banks, it is also fundamentally important to be guaranteed access to information containing sustainability criteria, as well as for the information available based on a unified methodology to be automatically processable. In the absence of this, and in the event that manual information collection and evaluation becomes a necessity, products that are "green" in terms of sustainability cannot be expected to become universal or mass products of mainstream financial markets, but will instead remain within the limits of a "niche" market.

With respect to sustainability, the financial regulatory environment is changing at numerous other points (including new microprudential capital requirements, supplementary disclosure requirements related to financial organisations, and framing of reference indicators), while new standardisations and labels are in the process of being elaborated (e.g. green securitisation, green bonds, ecolabelling).

Even in appraising the above developments, no miracles should be expected in this area. The impetus towards a supply of financing via the financial sector that takes sustainability factors into account and aims at "green" developments is in itself insufficient to attain the goals of sustainability. This is because the decision to make a green or a non-green investment is made not by financiers (if financing is even needed at all), but by the investors themselves. A breakthrough can therefore only be achieved through strict regulation of potential investments that require a green direction to be taken, or by applying suitable tools to stimulate an increase in demand for eco-financing. Promoting the involvement of private sources of financing in this area via targeted budgetary incentives and tax policies will also prove indispensable. 


\subsection{Technological development, digitalisation}

Digitalisation, more than being a simple question of technology, can result in a radical transformation in consumer needs related to finances, and thus market demand itself. Consumers expect rapid, reliable and secure services, primarily through intermediary channels and platforms which all enable a broad-ranging comparison and choice among substitute products. At the same time, with respect to new digital solutions, it is also expected that they should be at least as secure as services used earlier or through other channels, or that their spread should not endanger financial stability in the broader sense.

At the same time, digitalisation is also an important element of competitiveness. For this reason, it is essential for the regulatory framework to be innovationfriendly, and for it to promote the rapid and regulated spread, and safe operation, of evolutive digital technologies such as artificial intelligence and blockchain/ DL technology in the EU. Although the departing European Commission and the ECB have already begun to frame the regulatory environment for these technologies, it will be the incoming Commission's task to conclude and facilitate its implementation. To achieve this will also require a review of the current financial regulatory framework "with digital eyes," in cooperation with the financial sector, fulfilling the requirement that the rules permit currently available digital solutions to be applied at banks in a technology-neutral manner, that the current and future needs of bank clients with respect to digitalisation are served, and that the responsibilities for their use are assigned appropriately.

Decentralised financial technologies enable financial intermediation to take place with the help of new technologies, while omitting all or certain elements of the traditional financial intermediary chain. Although the application of these technologies may naturally increase choice and reduce excessive dependency of the financial system on certain institutions, thereby potentially enhancing financial stability, they also carry significant risks to stability within the current regulatory environment (which was built on a pre-digitalisation system) in the event of a major portion of financial services switching over to these channels beyond a certain level (see in detail FSB, 2019b). One essential incentive for such a switch is that the costs of the banking sector related to regulation rose substantially following the financial crisis, so that some financial services are diverted into cheaper, less regulated intermediary channels, while the recovering economy and parallel growth in financial markets hides a good portion of the related risks until the next cyclical downturn. From the perspective of the banking sector, the key expectation is that the authentic nature of regulation should be that the same system of regulatory requirements should apply based on the given pursued activity. This 
creates equal competitive conditions, without hindering the emergence of an environment of technology-neutral services that support innovation.

The "fuel" of the digital economy is data. A comprehensive approach to the European data economy is indispensable to preserve the global competitiveness of the European banking sector. The Payment Services Directive (PSD2) brought the "open banking" principle into the regulatory sphere, opening up banks' databases to prudentially non-regulated, and thus riskier players via interfaces that are accessible free of charge. Without even examining the consumer protection aspects of this, the question remains of why the obligation to share data for free is confined merely to the banking community. Parallel with the regulatory handling of this issue, the banking sector should be ready to integrate the exploitable databases of other sectors into its own service chain.

Besides the opportunities created by digitalisation, there also needs to be a precise awareness of the dangers that lurk for the banking sector. Among the EU's regulatory priorities in recent years, cybersecurity stands out. The focus of this is the NIS Directive (Directive (EU) 2016/1148), coupled with the strengthened powers of the European Union Agency for Cybersecurity (ENISA), which have accorded it a central role in shaping a new cybersecurity certification framework. Specific defensive measures are of course the task of individual institutions; however, these can only be truly effective in a regulatory environment that is free of overlaps and contradictory requirements. To achieve this, in the case of any piece of banking regulation, requires that the exigencies of digitalisation and cybersecurity already be taken into account in the early stages of preparation of drafts.

The digital sphere today, of which the banking system is one element, is a complex network of many participants. From the perspective of security, this network is only as strong as its weakest link. Consequently, genuine cyber defence requires a holistic approach. Besides banking and other key players, the security requirements of non-banking participants must also be managed at the regulatory level. With respect to the handling of incidents, it is likewise important to establish efficient, standardised and reciprocal sharing of information between authorities, banks and other sectors, and for authorities to share the lessons learned from individual incidents - and their supplementary guidance - with market players.

\subsection{Participation of the banking sector in the fight against financial crime}

The banking sector today, by means of various due diligence, transaction monitoring and reporting obligations, has become by far the greatest private sector collaborator in the fight against financial crime - extending not only to traditional financial fraud, but also money laundering, the financing of terrorism, and the 
dodging of international financial sanctions. The most recent events occurring as a consequence of the economic crisis or geopolitical developments (the heightened terror threat, the migration crisis, and scandals related to money laundering and financial sanctions) have motivated European authorities to introduce additional stringent measures. The transformation of the global order has by no means slowed down or reached completion, and this may yet trigger further regulatory reactions in future.

As a consequence of the increasing globalisation of financial systems, the struggle against financial crime across national borders is ongoing on multiple levels, with the activity of banks being just one element. At present, authorities provide only partial feedback and support towards the development of affected banking activities, with the regulations followed by banks tending to take the form of administrative tasks or a kind of gate-keeping activity with respect to the institutions themselves, while the true role of banks in actual developments is scarcely or not at all clear within the process as a whole. The upshot of this is that banks have an almost impossible task in weighing individual suspicious transactions from the perspective of risk, and for this reason - through strictly observing the rules tend to overburden the authorities with data.

The intention of the European Commission (see proposal EC, 2017) for financial authorities at EU level to play a central coordinating role, at least in activities countering money laundering or the financing of terrorism, while strengthening communication between national and supranational authorities, represents a step forward on this issue. The challenge of the coming period on the part of the banking sector will be to ensure that the new institutional framework provides for a risk-based approach. In addition, with better cooperation between supervisory authorities and banks, broader-ranging sharing of information across borders must be established through better-targeted and more productive reporting obligations, or with the help of shared digital platforms such as publicly accessible KYC databases, where the data of legal entities and their ultimate owners can be known. All this would dramatically improve the efficiency of systems preventing money laundering and the financing of terrorism.

\subsection{Financial literacy}

Banks are obviously partners in the everyday life of both the public and companies. It is important for clients, no matter in which capacity they enter into contact with their bank, and whether they have financing requirements as retail customers, individual entrepreneurs or companies, to be able to adequately assess and articulate their needs for banking, investment or other services, and to 
evaluate and make a choice from among the offered alternatives. To this end, it is essential to enhance citizens' financial awareness through knowledge-building and educational activities.

Today complex, sometimes inconsistent regulation, combined with the operational paradigm shift brought by digitalisation, is generating a rapid evolution of financial products, which can only be expected to intensify further in the near future. In many cases, the changes transform the parameters of financial products or product structures so quickly that even experts have difficulty fully comprehending the processes. Even amid these changing circumstances, however, the requirements for educational content preparing students in the concepts and fundamental interconnections of the financial world are extremely low, while the standard at which they are taught is likewise insufficient to ensure that young people leaving school have at least a satisfactory level of knowledge. It is no mistake to assert that raising financial awareness and literacy to a satisfactory level would be an important macroprudential measure; however, no radical change in this direction can be observed in public education to this day, despite national authorities being able to report some partial successes in this regard.

The regulatory trend in consumer protection is tending towards the provision of an ever-wider range of information, and the expectation that risk elements and fees to be paid by customers for financial services are broken down and presented in increasing detail. At the same time, service providers in turn demand an increasing level of familiarity with consumers, including - in the case of certain more complex services - extensive disclosure of their financial knowledge and capabilities, income and wealth status, financial motivations and behaviour, while the limits of such information-gathering remain unclear with respect to constitutional rights pertaining to the protection of personal data. All this is designed to help close the gap between the knowledge of those concerned and the risk characteristics of the products they wish to utilise, a gap that is partly due to their inadequate financial preparedness. This is to say that it is financial institutions themselves which must apply administrative tools to partly compensate for the aforementioned deficiencies in public education.

The continuing challenge before the financial sector in the coming period will thus be how to harness its own resources to helping expand financial awareness and literacy in society, and to simultaneously motivate the authorities responsible for national education to ensure an adequate grounding for young people leaving public education to navigate a basic path through their finances, while finding the correct balance between the broadly expected level of knowledge and the interests of the consumer as protected by regulation. The efforts of banks may be served not only by a possible reduction in administrative burdens, but also by the potential 
of generally expanding financial literacy to simultaneously improve the customer experience when using products, in turn enhancing trust in the banking sector.

When discussing the ageing of the population, we often hear about issues related to pension systems, and within this voluntary pension savings models, but rarely about the specific impact of this phenomenon on everyday finances, and hence directly on the banking sector. The most recent summit of the G2o in Osaka nevertheless raised this issue among global regulatory topics ( $\left.\mathrm{G}_{2} \mathrm{O}, 2019\right)$. The document serving as the basis for discussion (GPFI, 2019) summarises the most important steps under eight points, the central element of which is the training and preparation of those concerned for the changing financial skills and needs of old age. The schedule to be worked out by 2020 will doubtless determine important tasks with respect to both financial regulatory authorities and market players.

\subsection{Profitable operation of the banking sector}

The issues discussed so far - upholding of the achievements attained in the domain of stability and responses to the challenges of the future - cannot omit the presence of a banking sector operating profitably across multiple economic cycles. Based on data from the ECB (ECB, 2019), euro area banks' average return on equity (ROE), at around 6\%, currently falls short of the $8-10 \%$ attained by their international competitors, while their costs of capital reach $8 \%$. The problems can be attributed to both cyclical and structural factors, a portion of which the banking sector will outgrow, such as economic and related credit growth, improving non-performance indicators and declining stocks of NPLs. Others - for example, efficiency problems, overbankedness in certain territories - will remain present.

The most important challenges related to profitable operation for European banks today are the almost decade-long low interest rate environment, factors impeding cross-border financial activity, and significantly increased regulatory costs.

The low interest rate environment erodes banks' net interest income on several fronts, of which two are perhaps the most important. Firstly, there are the closeto-zero or negative interest rates typical on the short side, which can be passed on to depositors only within restricted parameters, or not at all. Secondly, a basic function of banks is maturity transformation, and since yield curves are flat in a low interest rate environment, this likewise keeps the resultant interest rate differential narrow. However, it follows from the nature of economic cycles that a low interest rate environment cannot be regarded as an underlying circumstance that demands constant adjustments, as sooner or later inflation-anchored monetary policies that prioritise price stability will demand monetary tightening, and then interest rates will also stabilise at a higher level. Despite efforts to create a 
single market, many elements of the EU financial market remain fragmented; even so, though managing this places a significant demand on resources, it can be achieved and may yet prove a profitable move in the context of economies of scale. At the same time, an uncoordinated regulatory environment, which is thus costly for the sector, can only be alleviated with committed action on the part of legislators. As part of this, it is important that the fulfilment of global regulatory obligations should take distinctive European features into account, particularly in the context of divergent financing of investments, SMEs and real estate.

\section{SUMMARY}

More than a decade following the great financial crisis, significant tasks continue to emerge that require additional financial resources and administrative measures in connection with the implementation of regulations that were drawn up based on the lessons learned from the crisis, both in the global and European sphere. Complicating this are EU integration processes that received great impetus in the wake of the crisis, in particular financial integration. Alongside this, sustainable growth and digitalisation have accelerated or strengthened as worldwide phenomena, radically transforming social and economic conditions within a short period of time, and thus also requiring the banking sector to adapt quickly and inevitably. Assessing the combined impact of the changes, and managing regulatory inconsistencies and overlaps, is in the fundamental interests of the sector, since even in this way adaptation requires significant financial, material and human resources. All of this must be carried out without the EU's financial stability or the competitiveness of the sector being compromised by problems related to banks' profitability or ability to accumulate capital, which is currently being eroded on several fronts. Regaining and retaining society's trust with respect to the banking sector is a task at the European level, as is ensuring the global competitiveness of the European banking sector. 


\section{REFERENCES}

BCBS (2017): High-level summary of Basel III reforms. December, ISBN 978-92-9259-118-2 (online), https://www.bis.org/bcbs/publ/d424_hlsummary.pdf.

BCBS (2019a): Survey on the interaction of regulatory instruments: results and analysis. Basel Committee on Banking Supervision, Working Paper 35, March, ISBN 978-92-9259-257-8 (online), https://www.bis.org/bcbs/publ/wp35.pdf.

BCBS (2019b): Proportionality in bank regulation and supervision - a survey on current practices. March, ISBN 978-92-9259-261-5 (online), https://www.bis.org/bcbs/publ/d46o.pdf.

EBA (2018): Risk Assessment of the European Banking System, December, ISBN 978-92-9245-491-3, https://eba.europa.eu/documents/10180/2518651/Risk_Assessment_Report_December_2018.pdf.

EBA (2019): BASEL III Monitoring Exercise - Results Based on Data as of 30 June 2018, March, https://eba.europa.eu/documents/10180/2551996/Basel+III+Monitoring+Exercise+Report++data+as+of+3o+June+2018.pdf/a8f383db-79f5-4d41-a8f8-3fd76fodba3o.

EBF (2019): Boosting Europe - Building Trust and Supporting Growth in Europe, EBF recommendations for the EU 2019-2024 legislative cycle and beyond, https://www.ebf.eu/wpcontent/uploads/2019/o5/EBF_Building-Trust-and-Supporting-Growth-in-Europe_Final.pdf.

EC (2015a): A Bizottság közleménye az Európai Parlamentnek, a Tanácsnak, az Európai Gazdasági és Szociális Bizottságnak és a Régiók Bizottságának: Cselekvési terv a tőkepiaci unió megteremtésére, szeptember 30., https://eur-lex.europa.eu/legal-content/HU/TXT/PDF/?uri=CELEX:520 ${ }_{15} \mathrm{DC} 0468 \&$ from $=\mathrm{EN}$.

EC (2015b): Javaslat az Európai Parlament és a Tanács rendelete a 806/2014/EU rendeletnek az európai betétbiztosítási rendszer létrehozása érdekében történő módosításáról, https://eur-lex. europa.eu/legal-content/EN/TXT/?uri=CELEX:52015PC0586.

EC (2017): Javaslat az Európai Parlament és a Tanács rendelete az európai felügyeleti hatóság (Európai Bankhatóság) létrehozásáról szóló 1093/2010/EU rendelet; az európai felügyeleti hatóság (Európai Biztosítás- és Foglalkoztatóinyugdíj-hatóság) létrehozásáról szóló 1094/2010/EU rendelet; az európai felügyeleti hatóság (Európai Értékpapír-piaci Hatóság) létrehozásáról szóló 1095/2010/ EU rendelet; az európai kockázatitőke-alapokról szóló 345/2013/EU rendelet; az európai szociális vállalkozási alapokról szóló 346/2013/EU rendelet; a pénzügyi eszközök piacairól szóló 600/2014/EU rendelet; az európai hosszú távú befektetési alapról szóló (EU) 2015/760 rendelet; a pénzügyi eszközökben és pénzügyi ügyletekben referenciamutatóként vagy a befektetési alapok teljesítményének méréséhez felhasznált indexekről szóló (EU) 2016/1011 rendelet; valamint az értékpapírokra vonatkozó nyilvános ajánlattételkor vagy értékpapíroknak a szabályozott piacra történő bevezetésekor közzéteendő tájékoztatóról szóló (EU) 2017/1129 rendelet módosításáról, https://eur-lex.europa.eu/legal-content/HU/TXT/HTML/?uri=CELEX:52017PCo536.

EC (2018a): A Bizottság közleménye az Európai Parlamentnek, az Európai Tanácsnak, a Tanácsnak, az Európai Központi Banknak, az Európai Gazdasági és Szociális Bizottságnak és a Regiók Bizottságának. Cselekvési terv: A fenntartható növekedés finanszírozása, 2018. március 8., https:// eur-lex.europa.eu/legal-content/HU/TXT/HTML/?uri=CELEX:52018DCoo97\&from=EN.

EC (2018b): Javaslat az Európai Parlament és a Tanács rendelete a fenntartható befektetések előmozdítását célzó keret létrehozásáról, május 24., https://eur-lex.europa.eu/legal-content/EN/TXT/? qid=1561628853517\&uri=CELEX:52018PC0353.

EC (2018c): Tőkepiaci unió: ideje megújítani az erőfeszítéseket a beruházások, a növekedés és az euró erősebb szerepének megvalósítása érdekében. Közlemény, https://eur-lex.europa.eu/legalcontent/EN/TXT/?qid=1561621092340\&uri=CELEX:52018DC0767.

Carmassi, J. -Dobkowitz, S. - Evrard, J. - Parisi, L. - Silva, A. - Wedow, M. (2018): Completing the Banking Union with a European Deposit Insurance Scheme: who is afraid of crosssubsidisation? European Central Bank, Occasional Papers No 208/11 April, https://www.ecb. europa.eu/pub/pdf/scpops/ecb.op208.en.pdf?557c7f15bddfac62f842fdo8920b1e6e. 
ECB (2019): Euro area banks: the profitability challenge, keynote speech by Luis de Guindos, VicePresident of the ECB, at the ABI annual conference "Banking Union and Basel III - risk and supervision 2019", Rome, 25 June, https://www.ecb.europa.eu/press/key/date/2019/html/ecb. sp190625 6d33411cff.en.html?utm_source=European+Banking+Federation+newsletters+and +updates\&utm_campaign=7d50725a6d-EMAIL_CAMPAIGN_2018_04_25_COPY_o1\&utm_ medium=email\&utm_term=0_o88668d33b-7d50725a6d-80169247\&mc_cid=7d50725a6d\&mc_ eid $=2$ c68e3oodb.

FSB (2019a): Letter to ISDA on derivative contract robustness to risks of interest rate benchmark discontinuation, 12 March, https://www.fsb.org/wp-content/uploads/P150319.pdf.

FSB (2019b): Decentralised financial technologies. Report on financial stability, regulatory and governance implications, 6 June 2019, https:/www.fsb.org/wp-content/uploads/Po60619.pdf.

G20 (2016): G20 Leaders' Communiqué: Hangzhou Summit, 5 September, 18. pont, http://www.g2o. utoronto.ca/2016/160905-communique.html.

G2o (2019): G2o Osaka Leaders' Declaration, Osaka, Japan, 29 June, 7. pont, http://www.g2o. utoronto.ca/2019/2019-g20-osaka-leaders-declaration.html.

GFPI (2019): Global Partnership for Financial Inclusion - G2o Fukuoka Policy Priorities on Aging and Financial Inclusion, G2o Finance Ministers and Central Bank Governors Meeting, Fukuoka 8-9 June, http://www.gpfi.org/publications/g2o-fukuoka-policy-priorities-aging-and-financialinclusion.

Regulation (EU) 2016/1011: Az Európai Parlament és a Tanács (EU) 2016/1011 rendelete (2016. június 8.) a pénzügyi eszközökben és pénzügyi ügyletekben referenciamutatóként vagy a befektetési alapok teljesítményének méréséhez felhasznált indexekröl, valamint a 2008/48/EK és a 2014/17/ EU irányelv, továbbá az 596/2014/EU rendelet módosításáról, https://eur-lex.europa.eu/legalcontent/HU/TXT/HTML/?uri=CELEX:32016R1011\&from=EN.

Regulation (EU) 2019/876: Az Európai Parlament és a Tanács (EU) 2019/876 rendelete (2019. május 20.) az 575/2013/EU rendeletnek a tőkeáttételi mutató, a nettó stabil forrásellátottsági ráta, a szavatolótőkére és a leírható, illetve átalakítható kötelezettségekre vonatkozó követelmények, a partnerkockázat, a piaci kockázat, a központi szerződő felekkel szembeni kitettségek, a kollektív befektetési formákkal szembeni kitettségek, a nagykockázat-vállalások és az adatszolgáltatási és nyilvánosságra hozatali követelmények tekintetében történő módosításáról, valamint a 648/2012/EU rendelet módosításáról, https:/eur-lex.europa.eu/legal-content/EN/ TXT/?uri=celex:32019Ro876.

Regulation (EU) 2019/877: Az Európai Parlament és a Tanács (EU) 2019/877 rendelete (2019. május 20.) a 806/2014/EU rendeletnek a hitelintézetek és a befektetési vállalkozások veszteségviselő és feltőkésítési képessége tekintetében történő módosításáról, https://eur-lex.europa.eu/legalcontent/EN/TXT/?uri=CELEX:32019Ro877.

Directive (EU) 2016/1148: Az Európai Parlament és a Tanács (EU) 2016/1148 irányelve (2016. július 6.) a hálózati és információs rendszerek biztonságának az egész Unióban egységesen magas szintjét biztosító intézkedésekről, https://eur-lex.europa.eu/legal-content/HU/TXT/ $\mathrm{PDF} /$ ?uri=CELEX:32016L1148.

Directive (EU) 2019/878: Az Európai Parlament és a Tanács (EU) 2019/878 irányelve (2019. május 20.) a 2013/36/EU irányelvnek a mentesített szervezetek, a pénzügyi holding társaságok, a vegyes pénzügyi holding társaságok, a javadalmazás, a felügyeleti intézkedések és hatáskörök, valamint a tőkefenntartási intézkedések tekintetében történő módosításáról, https://eur-lex.europa. eu/legal-content/EN/TXT/?uri=CELEX:32019Lo878.

Directive (EU) 2019/879: Az Európai Parlament és a Tanács (EU) 2019/879 irányelve (2019. május 20.) a hitelintézetek és a befektetési vállalkozások veszteségviselő és feltőkésítési képessége tekintetében a 2014/59/EU irányelv, valamint a 98/26/EK irányelv módosításáról, https://eur-lex.europa. eu/legal-content/EN/TXT/?uri=CELEX:32019Lo879. 